\title{
Teachers Attitude towards Use of ICT in Technical and Non-Technical Institutes
}

\section{Sameena Farrukh}

\author{
Training Professional, Department of Education and Research, NITTTR, Bhopal,India
}

\section{Shireesh Pal Singh}

\author{
Center for Education, Central University of Punjab, Bathinda, Punjab.151001, India
}

\section{Doi:10.5901/jesr.2014.v4n7p153}

\begin{abstract}
In this study the group of teachers working in technical colleges and non-technical colleges both are selected to find out their attitudes towards use of ICT as their instructional resources in classrooms. As it is the fact that normally in technical colleges the teachers themselves have quite a good knowledge and are well aware with new technologies and therefore for these teachers the use of ICT as their instructional resource is not a big deal whereas the teachers of non-technical background may or may not be well aware of these new technological issues and therefore for these teachers it can be little difficult to adopt ICT as their instructional resources and they feel more convenient with the traditional mode of instructions in classrooms. Results revealed that there is a significant differences between the Mean attitude scores towards use of ICT of technical and nontechnical institute teachers.
\end{abstract}

Keywords: Attitude, Technical, Non-Technical, Information and Communication Technology

\section{Inroduction}

In recent years, ICT-related Initiatives are adopted and implemented by education systems with greater appreciation of their complexity. A major aspect of the complexity involved with ICT integration into education systems is based on the many factors involved with it including factors associated with the human side of the integration (e.g. teachers, on-going support, trainers, and headmasters) and the technological side of it (e.g. access to computers, technical support, and the e-materials). During the early attempts of integrating computers into education systems the technology itself was over emphasized at the cost of the human side. These attempts were based on the assumption that technology can revolutionize education and therefore, resources and efforts were diverted to providing schools with computers and other technologies. During that stage, technology was conceived as an end in itself, which resulted in computers being distributed to schools with little thought given to their best use (Richardson, 2005; Veen, 1993).

As a developing country, India is striving to improve its education system for the knowledge era. ICT professional development courses are integral to improve educational practices as they empower teachers with knowledge and skills required for integrating ICT in the classroom. Such moves and actions need to be guided with research. The education practices in India need sound and grounded.

Research studies in the past decade have shown that computer technology is an effective means for widening educational opportunities, but most teachers neither use technology as an instructional delivery system nor integrate technology into their curriculum. Studies reveal a number of factors influencing teachers' decisions to use ICT in the classroom: non-manipulative and manipulative school and teacher factors. These factors are interrelated. The success of the implementation of ICT is not dependent on the availability or absence of one individual factor, but is determined through a dynamic process involving a set of interrelated factors. It is suggested that ongoing professional development must be provided for teachers to model the new pedagogies and tools for learning with the aim of enhancing the teaching-learning process (Baylor \& Ritchie, 2002). However, it is important for teacher trainers and policy makers to understand the factors affecting effectiveness and cost-effectiveness of different approaches to ICT use in teacher training so training strategies can be appropriately explored to make such changes viable to all.

The establishment of Information and Communication Technology infrastructure is a vital sustainable development for academic programs in higher education. It is important to interlink primary schools and knowledge- generating institutions like universities. Teacher training and students contact require good communication links. New technologies 
can be used to improve the quality of life in rural areas, and strengthen the village communities through Educational Technology(Chaudhary, 2004). Several initiatives across the world show the practical value of the sophisticated technology for purposes of Education. Students at different geographical locations can be linked with their teacher and each other through a group video hook-up. Educational Technology should promote understanding of land use problems, encourage sustainable land use and provide techniques, which facilitate customary land ownership. Education should provide strategies to help those emerging from traditional society to cope with the cash economy.

Thus it is clear from the above description that now-a-days ICT is being used in almost every sphere of life including education. It is for this reason that the computers and internet are directly and indirectly affecting the constructivism of Adolescents, which is very important even for the technological progress. It is necessary to find out the effect of ICT on the education system. The rapid developments of the Internet make it convoluted to understand its current impact, alone its upcoming impact. In other words, while the number of users rises arithmetically, the value and impact of the Internet arise exponentially.

To create effective learning opportunities using ICT the teachers have major role as facilitators and therefore within this framework teachers should be encouraged to linked up more actively and professionally expert. Currently there is an expectation that teachers should be 'oracle' have fairly complete mastery of what is being taught and should be able to guide students to ensure the proper use of ICT resources. The students using virtual learning environments has access to a diversity of knowledge resources and ways of easily tracking individual and group learning process and therefore rather than trying to mold teachers attitudes the opportunities should be offered to the teachers to let them become learners, to challenge them in a process of professional development in order to develop those skills and practices that are most helpful to create learning environments using information and communication technology(Ramesh Chandra,2005).

Teacher education programs at the pre-service and in-service levels must have ample scope for inducting pedagogic skills and management of technologies as important components of teaching learning environment to enhance efficacy to transaction. These need to integrate teaching-related practices with the existing methodology course and introduce specialized course to equip the student teachers with skills to operating and maintaining hardware, acquiring and utilizing software of different kinds i.e. structured textual materials, teaching aids, audio-visual cassettes, multimedia, CD ROMs and sharing information through networking in collaborative and participative methods. The application of ICT in the education setting need to be cultivated promoted and nurtured(Bosley\& Moon, 2003).

The present study has been undertaken to find out and analyses the attitude of teachers engaged in higher education towards the use of ICT. In this study the group of teachers working in technical colleges and non-technical colleges both selected to find out their attitudes towards using ICT as their instructional resource in their classrooms. As it is the fact that normally in technical colleges the teachers themselves have quite a good knowledge and are well aware with new technologies including information and communication technologies and therefore for these teachers the use of ICT as their instructional resource is not a big deal where as the teachers of non technical backgrounds may or may not be well aware of these new technological issues and therefore for these teachers it can be little difficult to adapt ICT as their instructional resource and they feel more convenient with the traditional mode of instructions in classrooms, Hence the present study will be helpful to find out the attitude of teacher'sin these prospects.

\section{Objectives of the Study}

1. To find out the Attitude of technical and nontechnical teacher's towards ICT.

2. To compare the attitude of technical and nontechnical teachers who do not use ICT.

3. To compare the attitude of technical and nontechnical teachers who use ICT.

4. To Study the effect of sex on attitude of technical and nontechnical teachers.

\section{Hypothesis of the Study}

1. There is no significant difference between mean attitude score of technical and nontechnical teacher's towards ICT.

2. There is no significant difference between mean attitude score of technical and nontechnical teachers who do not use ICT.

3. There is no significant difference between mean attitude score of technical and nontechnical teachers who use ICT. 
4. There is no significant difference between mean attitude score of male and female teachers of Technical Institutes towards use of ICT.

\section{Methods of the Study}

In this study the researcher has used Descriptive survey method to find out the effect of use of ICT by teachers of technical and non technical Background. Independent variable has been treated at two level- users and non-users of ICT, both of the sex, and both the stream Technical and non-technical. So the research design was factorial research design.Sample consists 200 teachers of both the sexes and of two streams (technical and nontechnical background) which was selected from Colleges of Bhopal city.

\section{Tool of the Study}

Self-made questionnaire, Teacher's Attitude towards ICT have been used for data collection. Researcher developed teaches attitude scale to assess the attitude towards ICT of the technical and non technical teachers. This is a five point scales and consists 40 questions

\section{Results and Interpretations}

The purpose of this study was to compare the attitude of technical and non technical teachers towards use of ICT. Beside, this study is intended to know the relationship between teachers attitude towards use of ICT.

Table 1.1: Mean attitude score of technical and nontechnical Institute teacher's towards ICT.

\begin{tabular}{|c|c|c|c|c|c|c|c|}
\hline variable & Group & $\mathrm{N}$ & $\mathrm{M}$ & $\mathrm{SD}$ & $\mathrm{df}$ & 't' & Result \\
\hline \multirow{2}{*}{$\begin{array}{c}\text { Attitude } \\
\text { towards ICT }\end{array}$} & Technical Ins. Teachers & 100 & 1.49 & 7.76 & \multirow{2}{*}{198} & \multirow{2}{*}{2.98} & \multirow{2}{*}{ Sig. at $0.05 \%$} \\
\cline { 2 - 5 } & Non technical Ins. Teachers & 100 & 1.05 & 12.8 & & \\
\hline
\end{tabular}

From above table it is evident that ' $\mathrm{t}$ ' value is 2.98 at $0.05 \%$ level of significance which is greater than table value.Therefore our calculated value is significant at $0.05 \%$ level of significance. Hence, the null hypothesis is rejected. Finally we can conclude that there is a significant difference between the Mean attitude score towards use of ICT of technical and non technical institute teachers.

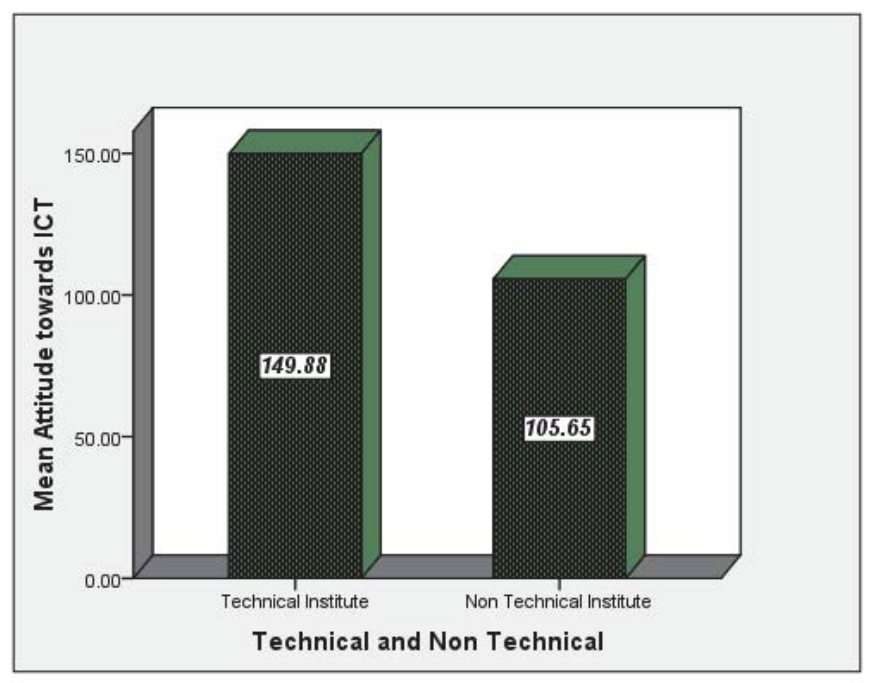

Figure 1.1: Mean attitude score of technical and nontechnical Institute teacher's towards ICT

The finding of the hypotheses, $\mathrm{H}-1$ illustrated that there is a significant differences between the Mean attitudes score 
towards ICT of technical and non technical institute teachers. Due to lack of knowledge, efficiency and unavailability of resources of internet and computer in non-technical institute further Interest is also major factor towards use of ICT in technical and non technical institute teachers. Hence due to this reason there is significant differences between the Mean attitudes score towards ICT of technical and non technical institute teachers.

Table 1.2: Mean attitude score of technical and nontechnical Institute teacher's who do not use ICT.

\begin{tabular}{|c|c|c|c|c|c|c|c|}
\hline variable & Group & $\mathrm{N}$ & $\mathrm{M}$ & $\mathrm{SD}$ & $\mathrm{df}$ & 't' & Result \\
\hline \multirow{2}{*}{ Attitude towards ICT } & Technical Ins. Teachers & 12 & 1.14 & 9.10 & \multirow{2}{*}{81} & \multirow{2}{*}{2.69} & \multirow{2}{*}{ Sig. at $0.05 \%$} \\
\cline { 2 - 6 } & Non technical Ins. Teachers & 71 & 1.03 & 12.8 & & & \\
\hline
\end{tabular}

From above table it is evident that our t value is 2.69 at $0.05 \%$ level of significance which is greater than table value at $0.05 \%$ level of significance. Hence, the null hypothesis is rejected. Finally we can conclude that there is a significant difference between the Mean attitude score towards ICT of technical and non technical institute teachers who do not use ICT.

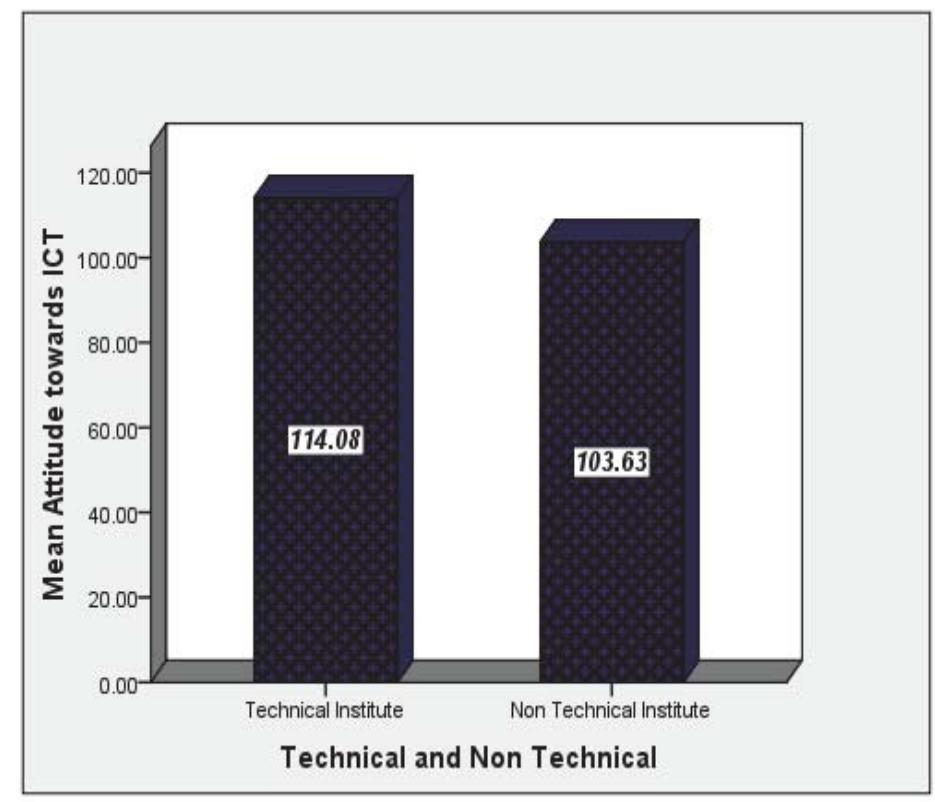

Figure 1.2: Mean attitude score towards ICT of technical and non technical institute teachers who do not use ICT.

The finding of the hypotheses, $\mathrm{H}-2$ illustrated that there is a significant differences between the Mean attitudes score towards ICT of technical and non-technical institute teachers which may be due to lack of knowledge and unavailability of resources of internet and computer in non technical institute.

Table 1.3: Mean attitude score of technical and nontechnical Institute teachers who use ICT.

\begin{tabular}{|c|c|c|c|c|c|c|c|}
\hline variable & Group & $\mathbf{N}$ & $M$ & SD & $\mathrm{df}$ & ' $t$ ' & Result \\
\hline Attitudo towards ICT & Technical Ins. Teachers & 88 & 1.49 & 8.91 & \multirow{2}{*}{115} & \multirow{2}{*}{18.9} & \multirow{2}{*}{ Sig. at $0.05 \%$} \\
\hline & Non technical Ins. Teachers & 29 & 1.40 & 11.5 & & & \\
\hline
\end{tabular}

In order to test the H-3 "There will be no significant difference between the Mean attitude score towards ICT of technical and non technical institute teachers who use ICT. From above table it is evident that ' $t$ ' value is 18.9 at $0.05 \%$ level of significance. The table value for 115 degree of freedom. Our calculated' value, that is 18.9 greater than table value at $0.05 \%$ level of significance, Hence, the null hypothesis is rejected, on this basis we can conclude that there is a significant difference between the Mean attitude score towards ICT of technical and non technical institute teachers who 
use ICT .

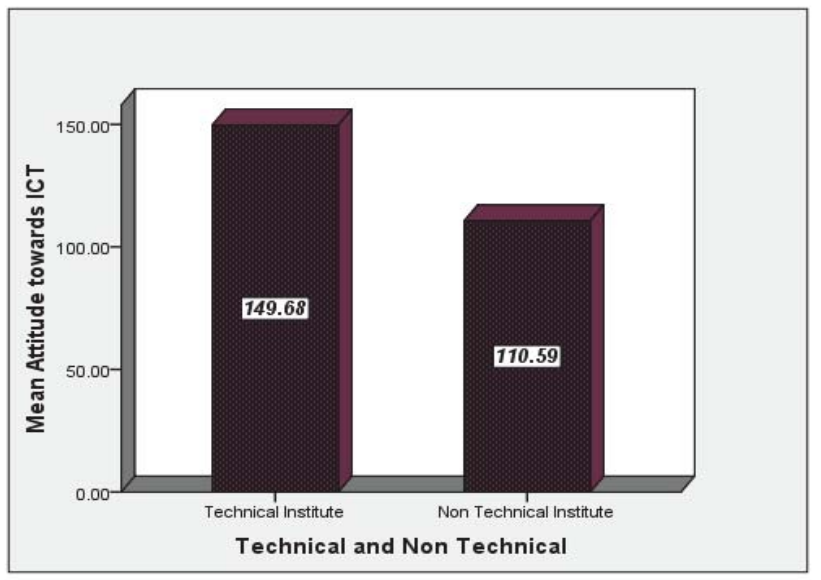

Figure 1.3: Mean attitude score towards ICT of technical and non technical institute teachers who use ICT .

The finding of the hypotheses, $\mathrm{H}-3$ illustrated that there is a significant differences between the Mean attitudes score towards ICT of technical and non-technical institute teachers.

The fourth hypothesis stated that "There is no significant difference between mean attitude score of technical and non technical male and female teachers who do not use ICT . This hypothesis is verified and shown in table 1.4.

Table 1.4: Mean attitude score of technical and nontechnical Institute male and female teacher's who do not use ICT.

\begin{tabular}{|c|c|c|c|c|c|c|c|}
\hline variable & Group & $\mathrm{N}$ & $\mathrm{M}$ & $\mathrm{SD}$ & $\mathrm{df}$ & 't' & Result \\
\hline \multirow{2}{*}{ Attitude towards ICT } & Male & 31 & 1.12 & 10.2 & \multirow{2}{*}{81} & \multirow{2}{*}{4.38} & \multirow{2}{*}{ Sig. at $0.05 \%$} \\
\cline { 2 - 6 } & Female & 52 & 1.00 & 12.3 & & & \\
\hline
\end{tabular}

In order to test the $\mathrm{H}-4$ "There will be no significant difference between the Mean attitude scores towards ICT of technical and non technical institute male and female teachers who do not use ICT .from above table it is evident that our't' value is 4.38 which is greater than table value at $0.05 \%$ level of significance. Hence, the null hypothesis is rejected.

On this basis we can conclude that there is a significant difference between the Mean attitude score towards ICT of technical and non technical institute male and female teachers who do not use ICT.

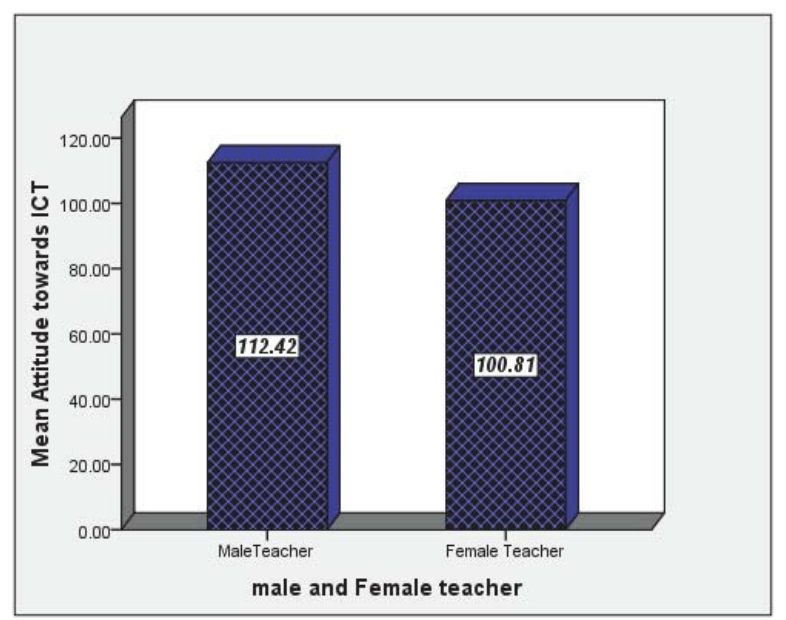

Figure 1.4: Mean attitude score towards ICT of technical and non technical institutemale and female teachers who do not use ICT. 
The finding of the hypotheses, $\mathrm{H}-4$ illustrated that there is a significant differences between the Mean attitudes score towards ICT of technical and non technical institute male and female teachers. Due to lack of knowledge and unavailability of resources of internet and computer in non technical institute. Interest is also major factor towards use of ICT in technical and non technical institute teachers who do not use ICT. Hence due to this reason there is significant differences between the Mean attitudes score towards ICT of technical and non technical institute male and female teachers who do not use ICT.

The fifth hypotheses stated that "There is no significant difference between mean attitude score of technical and non technical male and female teachers who use ICT.

Table 1.5: Mean attitude score of technical and nontechnical Institute male and female teacher's who use ICT

\begin{tabular}{|c|c|c|c|c|c|c|c|}
\hline variable & Group & $\mathrm{N}$ & $\mathrm{M}$ & $\mathrm{SD}$ & $\mathrm{df}$ & 't' & Result \\
\hline \multirow{2}{*}{ Attitude towards ICT } & Male & 69 & 1.37 & 19.7 & \multirow{2}{*}{115} & \multirow{2}{*}{1.8} & \multirow{2}{*}{ Sig. at $0.05 \%$} \\
\cline { 2 - 7 } & Female & 48 & 1.43 & 18.5 & & \\
\hline
\end{tabular}

In order to test the H-5 "There will be no significant difference between the Mean attitude score towards ICT of technical and non technical institute male and female teachers who use ICT. Our calculatedvalue which is 1.8 is lower than table value at $0.05 \%$ level of significance. Therefore our calculated value is not significant at $0.05 \%$ level of significance. Hence, the null hypothesis is accepted. Finally we can conclude that there is no significant difference between the Mean attitude score towards ICT of technical and non technical institute male and female teachers who use ICT.

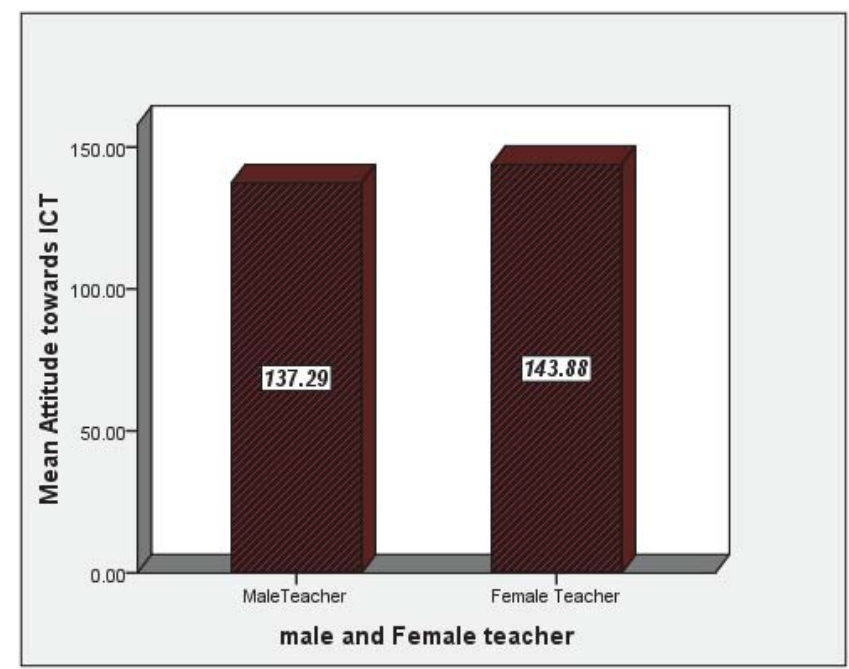

Figure 1.5: Mean attitude score towards ICT of technical and non technical institutemale and female teachers who use ICT

The finding of the hypotheses, $\mathrm{H}-5$ illustrated that there is no significant differences between the Mean attitudes scores towards ICT of technical and non technical institute male and female teacher's Use of ICT create interest and awareness towards Information and communication technology which is ultimately become the reason for no difference.

\section{Conclusion}

Integrating technology into classroom practices is one of the challenges in the 21st century. Effectively integrating ICT into teaching learning process is much more complicated than providing computers and securing a connection to the Internet. In fact, the integration of ICT is associated with a shift from instructive to constructivist philosophies of teaching and so, technology integration takes time to learn about the innovation, time to be adequately prepared to use it. In this respect, principals play an important role in applying different strategies such as change agent, lifelong learner, principal supporter, and resource provider to implement ICT in technical institute. Thus, researcher should be able to identify and 
articulate a vision, provide an appropriate model, provide individualized support, simulateintellectual stimulation, foster acceptance of group goals, and achieve high performance expectations. They should have knowledge, skills and positive attitudes toward the implementation of ICT in institutes. In this way, they can create changes in their institutes by focusing on action and by converting their teachers to be leaders who will eventually become agents of change. Therefore, teachers can play a role as a leader when they are committed to a cause and are self managing .An examination of past research studies and reports on ICT implementation in institutes show that there are two main factors that affect teachers' uptake of ICT. These are manipulative and non-manipulative institute and teacher factors. Research on the implementation of ICT in institutes has also shown that these institute and teacher factors are interrelated. The success of the implementation of ICT is not dependent of the availability or absence of one individual factor, but is determined through a dynamic process involving a set of interrelated factors. Moreover, no single solution exists to address the immense challenges of ICT integration because different perspectives of integrating ICT can be chosen. It is a fact that teacher training programmes play an important role to provide the necessary leadership in training pre-service and in-service teachers to deal with the current demands of society and economy. They should model the new pedagogies and tools for learning with the aim of enhancing the teaching learning process. Moreover, teacher education institutions and programmes must help teachers to understand how the new technologies can best be used in the context of the culture, needs, and economic conditions of their country. Hence, building the capacity of teachers in the utilization of ICT for education requires long-term continuous development of the lead trainers, sharing of knowledge among teachers, partnerships and collaboration among educators and organizations, and support from principals and administrators. These factors must be available in order to create changes in the views towards ICT. Therefore, both teachers and trainers require ongoing support and opportunities to experiment with new skills and strategies over time.

\section{References}

Amareswaran, N., \& Singh, S. P. (2011). Teacher Education through Open and Distance Learning--Information and Communication Technology Based Pedagogy Integration. TechnoLEARN: an International Journal of Educational Technology, 1(1).http://indianjournals.com/ijor.aspx?target=ijor:tle\&volume=1\&issue=1\&article=005

Albirini, A. (2006).Teachers' Attitudes toward Information and Communication Technologies. Journal of Computer \& Education, 47, 373398.

Almusalam, S. N. (2001). Factors related to the use of computer technologies for professional tasks by business and administration teachers at Saudi technical colleges. (Doctoral Dissertation, the Ohio State University, 2001). ProQuest Digital Dissertations (UMI No. AAT 3011019).

Anderson, R. E., \& Dexter, S.L. (2000).School Technology Leadership: Incidence and Impact (Teaching, Learning, and Computing: 1998 National Survey Report\#6). Irvine, CA: Center for Research on Information Technology and Organizations, University of California, Irvine. Bangkok, U. (2004). Integrating ICTS into Education. Retrieved May 12, 2007, from ICT in Education: http://www.unescobkk.org/index.php?id=1793

Barker, P. (1999). Using intranets to support teaching and learning. Innovations in Education and Training International, 36(1), 3-10.

Bauer, J., \& Kenton, J. (2005). Technology integration in the schools: Why it isn't happening. Journal of Technology \& Teacher Education, 13, 519-526.

Baylor, A. L., \& Ritchie, D. (2002). What factors facilitate teacher skill, teacher morale, and perceived student learning in technology using classrooms?.Computers \& Education39, 395-414.

Becker H. J. (2001).How Are Teachers Using Computers for Instruction? Paper presented at the 2001 Annual Meeting of the American Educational Research Association, Seattle,March 2001.

Bennett, C. (1996), "Schools, Technology and Educational Leadership: A Framework for Change", NASSP Bulletin, Vol. 80 No. 577 , pp. 57-65.

Bennis, W., \& Nanus, B. (1985).Leaders: The Strategies for Taking Charge. New York: Harper and Row.

Benzie, D. (1995). IFIP Working Group 3.5: Using Computers to Support Young Learners. In J.D.Tinsley\& T.J. van Weert (Eds.), World Conference on Computers in Education VI: WCCE' 95 Liberating the Learner (pp. 35-42). London: Chapman \& Hall.

Berner, J. E. (2003).A Study of Factors That May Influence Faculty in Selected Schools of Education in the Commonwealth of Virginia to Adopt Computers in the Classroom.(Abstract Doctoral Dissertation, George Mason University, 2003). ProQuest Digital Dissertations (UMI No. AAT 3090718).

Bielaczyc, K., \& Collins, A. (1999). Learning Communities in Classrooms: A Reconceptualization of Educational Practice. In: C. Reigeluth (Ed.), Instructional-design theories and models. A new paradigm of instructional theory, (vol. 2, pp. 269-292). Mahwah, NJ: Lawrence Erlbaum Associates.

Bosley, C. \& Moon, S. (2003). Review of Existing Literature on the Use of Information and Communication Technology within an Educational Context. Centre for Guidance Studies, University of Derby.

Chao, Ching-Chin, (2001).Learning with the internet a qualitative and quantitative analysis of university students: Internet use and 
perception in Taiwan. Dissertation Abstract International, Vol. 62 (7) pp. 2392A.

Chaudhary Vineeta (2004).A comparative study of Urban and Rural High school Boys and Girls in Relation to Creativity, Psycho Lingua Vol. 34, No. (1).

Danwal,Kiran \& Singh Shireesh Pal (2012).Enhancing spiritualism in virtual world, Turkish Online Journal of Distance Education-TOJDE April 2012 Volume: 13 Number: 2 Notes for Editor-7http://files.eric.ed.gov/fulltext/EJ983624.pdf

Singh, Shireesh Pal., \& Dangwal, Kiranlata. (2011). Innovative Educational Methods. New Delhi Publishers.,p.25

Gakhar and Sushma (2003). Creativity Problem Solving and Personality, Psycho Lingua, Vol. 33, no.2

Kumar, M \& Shirur, S. (2003).Internet and its use in S.J. College of engineering: A case study, SRELS Journal of Information Management, 40(2), 169-176.

Pandian C.C. \& Rengarajan (2004). Effectiveness of Inquiry Training Modal on the Autonomy in learning and creativity of the students, Experiments in Education, Vol. XXXII, No.3

Robbins, Janice Irene, (2001).Making connections: Adolescent girls' use of the internet. Dissertation Abstract International, vol 62(8), pp. 27-35.

Padhan, A., \& Singh, Shireesh Pal (2010). Culminating Professional Ethics to Reduce ZPD Gaps in Teacher Education. Learning Community: An International Journal of Education \& Social Development, 1(1).

Singh, Shireesh Pal., \& Dangwal, Kiranlata. (2011). Innovative Practices in Education. New Delhi Publishers.,p.145

Wilson, Rebecca A. (1998).Student's user of the Internet for course related research: Factors which account for use or non use. Dissertation Abstract International, Vol 68(7). p. 25 